\title{
Operator Training Simulators for Biorefineries: Current Position and Future Directions
}

Joseph Isimite ${ }^{1}$, Frank Baganz ${ }^{1}$, Volker C. Hass ${ }^{1,2}$

${ }^{1}$ Department of Biochemical Engineering, University College London, Gordon Street, London, WC1H OAH ${ }^{2}$ Sustainable Bioprocess Engineering Research Group, Hochschule Furtwangen University, JakobKienzle-Str. 17, D-78054 Villingen-Schwenningen, Germany

1Corresponding Author: volker.hass@hs-furtwangen.de, Tel.: 077203074253

\section{Abstract}

Recent technological advances in the development of alternative energy sources, including biofuels, for transportation and energy requirements have demonstrated the need for highly skilled engineers and operators in the biotechnological industries. Although Operator Training Simulators (OTS) used in the traditional chemical process industries may be used to train biorefinery operators and engineers, several distinct aspects of bioprocess operations make their direct application limited. The development and deployment of OTSs for use in biotechnological processes is therefore beginning to gain increasing attention. This review paper will examine the present status of OTS development and use in biorefineries, including future considerations on how an OTS may be used to improve operator competence, maximise biorefinery operational efficiencies and protect people and the environment.

The general premise of an OTS is that model-based operator training simulators can be used to verifiably enhance the training of industrial operators to run complex biorefineries. Only a few examples of the design and application of OTSs in large-scale biorefineries have so far been reported. A discussion of the mathematical models used for OTS development is briefly presented, as well as available OTS design frameworks and vendors, including their benefits and drawbacks. The review concludes by looking at possible future directions of OTS development and use in biorefineries and their contribution in facilitating the transition to a bio-based economy.

\section{Keywords}

Simulator, biorefinery, OTS, bioprocess, education, competence

\section{Word count}

5965 words (excluding references and tables) 


\begin{tabular}{ll} 
Abbreviations \\
ABET & Accreditation board for engineering and technology \\
BCI & Biorefinery complexity index \\
COMAH & Control of major accident hazards \\
DCS & Distributed control system \\
DLL & Dynamic link libraries \\
FDA & Food and drug administration \\
FMEA & Failure modes and effects analysis \\
FMMS & Fermentation modelling and monitoring system \\
GUI & Graphical user interface \\
i-BOS & Interactive biorefinery operations simulator \\
IEA & International energy agency \\
KPI & Key performance indicator \\
OTS & Operator training simulator \\
PID & Proportional integral derivative (controller) \\
QbD & Quality by design \\
QFD & Quality function deployment \\
RPP & Recombinant protein production \\
SOP & Standard operating procedure \\
ToT & Transfer of training \\
VR & Virtual reality \\
& \\
\hline
\end{tabular}




\section{Introduction}

Operator training simulators (OTS) for use in several sectors including chemical and allied industries, gained increasing popularity from the middle of the twentieth century. This was brought about by the increasing complexity of process plants, with challenging automation and process control strategies that placed huge demands on the capabilities of process operators ${ }^{1}$. A number of review papers on the development and use of OTSs in the process industries exist in the published literature ${ }^{2-4}$. Recent technological advances in the development of alternative energy sources, including biofuels, for transportation and energy requirements have demonstrated the need for highly skilled engineers and operators. Although OTSs used in the traditional chemical process industries may be used to train operators of biorefineries, several distinct aspects of bioprocess operations make their direct application limited. The development and deployment of OTSs for use in biotechnological processes is therefore beginning to gain increasing academic interest ${ }^{5-7}$. A discussion of the different classes of training simulators is presented by Hass ${ }^{1}$.

Developing a functionally useful OTS for use in bioprocessing applications is an advanced mechatronic (mechanical-electronic) engineering design problem. This is because of the complex interaction of mechanical, electrical, automatic control, information technology and biological components. A systems engineering approach has been recommended as an effective means of approaching such a design problem $^{8}$. Such a methodology encourages a top down approach that ensures the effective integration of several disciplines to develop a product or process that satisfies clearly defined technological and customer requirements. The first attempt to apply established engineering design principles and methodology to biotechnology product and process development is given by Mandenius and Björkman ${ }^{9}$. The authors present a design approach that adapts design methods in biomedical and mechanical engineering to offer a structured approach in designing biotech products and processes. In addition to the existing complexity inherent in designing electro-mechanical systems, the presence of biological cells and molecules add an extra layer of complexity.

Today's advances in biotechnology have made it possible to use non-food lignocellulosic biomass for biofuels production, thereby reducing the immense pressure on food grain crops and arable land used for the production of first generation biofuels ${ }^{10}$. The above considerations mean that the search for more efficient ways to produce bioethanol and other biofuels such as biodiesel and biogas will intensify in the coming years. Thus there is a responsibility to provide fit-for-purpose education for the next generation of bioengineers and the right skill and training for process operators who will run the biorefineries of the future. In addition, operating a biorefinery often requires engineers and plant operators to work in hazardous conditions and operate complex equipment with little or no margins for error. This usually limits the amount of training that can be carried out safely on site without posing serious risks to personnel, plant equipment or the environment. It is therefore necessary to design safe systems and environments to train biorefinery process operators. Operator training simulators provide

the opportunity to expose personnel to hazardous situations in a safe, highly visual and interactive manner ${ }^{11}$.

Increased automation and reliance on safety-instrumented systems mean that complex biorefineries place huge demands on the competencies of plant operators and engineers. Operator training simulators for large-scale bioethanol plants can be used to significantly improve operator competence, and optimise operating scenarios leading to better product yields and quality ${ }^{7}$. The main benefit arises from the predictive capability of such an OTS system, which will allow an operator to adapt plant operating conditions following upset conditions to achieve desired future outcomes based on the output from the OTS.

Furthermore, the regulatory requirements in some countries place responsibilities on process plant owners to demonstrate that operators have been adequately trained to run a plant safely, without harming people or the environment. In the UK, the Control of Major Accident Hazards (COMAH) regulations 2015 places a legal responsibility on businesses to "take all necessary measures to prevent major accidents involving dangerous substances and limit the consequences to people and the environment of any major accidents which do occur"12. Part of this involves the identification of operator training needs, provision of training, and evaluation of training effectiveness. An OTS 
provides an effective means of demonstrating a responsible and robust approach to operator competence assurance.

In addition to the above, there are peculiar aspects of biorefineries that make them different to traditional refineries, requiring biorefinery operators and engineers to be trained differently. While the technologies for raw material and intermediate product conversion in a petroleum refinery are well established, significant research and development efforts are still ongoing to identify the most efficient methods for raw material transformation in biorefining operations. The IEA Bioenergy Task $42^{13}$ developed the Biorefinery Complexity Index $(\mathrm{BCl})$ that uses several factors to determine the level of complexity of a biorefinery. Such factors include the range of starting raw materials used, the number of primary products and co-products made, and the commercial readiness of the technology deployed. It is therefore important that OTSs developed for training biorefinery operators are readily adaptable to accommodate the changing technology landscape for biomass conversion to useful products. The strategies and tools used for biorefinery OTS development should be flexible enough to accommodate this variability.

The relative small scale of biorefineries compared to petroleum refineries is another area of difference. While there are a number of biorefineries for advanced biofuels that are still at the pilot and demonstration scales ${ }^{14}$, there are many commercial petroleum refineries in different parts of the world. The size of commercial scale biorefineries is also limited by several factors including feedstock and technology availabilities, and the market readiness of the final product ${ }^{15}$. Because of the smaller scale, the number of operators required to run a biorefinery is smaller than that required to run a petroleum refinery. Add to this the relative benign nature of the fluids processed in a biorefinery, in comparison to the toxic chemicals present in the petroleum refinery, and there is less requirement for bolt-on safety instrumented systems. As a result, operators in a biorefinery are relied upon to carry out more tasks, including safety critical tasks. An OTS provides a valuable means of quickly training an operator to effectively carry out these operational tasks.

Feedstock variability in biorefineries is a factor that places additional demands on operator competence. In a petroleum refinery, the feedstock is relatively homogeneous, apart from the presence or absence of impurities such as sulphur that determine the pre-processing steps required. The feedstock for a biorefinery, on the other hand, can have varying bulk properties that require different operational strategies to maintain product yields and quality ${ }^{13}$. At a more demanding level, a biorefinery may be configured to process different types of feedstocks, depending on the complexity of the facility. An OTS can be used to train operators to adopt the correct operational strategy suitable for the feedstock being processed. 


\section{Modern biorefineries}

Biorefineries utilise different sources of biomass to produce liquid and gaseous fuels, often referred to as biofuels. The origin of today's biofuel industry can be traced to the Chemurgy movement of the early $20^{\text {th }}$ century, with a focus on making industrial products from agricultural raw materials ${ }^{16}$. It was argued by proponents of the movement, including Henry Ford ${ }^{17}$, that agricultural products and food by-products could be used to produce the chemicals necessary for modern life. The concept of a biorefinery emerged from this early movement. Today, we know that the petrochemical route to useful chemicals, energy and transportation fuels, eventually outcompeted the biomass route due to raw material supply inconsistencies and huge bioprocessing costs. The current drivers for the renewed interest in meeting modern man's energy and fuel needs from biomass-based sources include growing sustainability concerns, the need for energy security, and a desire to boost agricultural productivities and efficiencies.

There are several traditional biofuel production facilities for the commercial manufacture of first generation biofuels. The major products from these biorefineries include bioethanol from sugar and starch based crops, biodiesel and mostly glycerol from oil based crops, and biogas from anaerobic digestion. Examples of feedstocks used for the production of first generation biofuels include sugarcane and sugar beets, corn, wheat, canola, soybean, and palm oil. Advanced technologies, on the other hand, are being developed for the manufacture of second or third generation biofuels. Intensive research and development efforts are being directed towards the deployment of cost competitive technologies to convert non-food feedstocks and waste to biofuels. There is also a drive to produce fuels with advanced properties that can be directly used in existing transportation engines and available distribution infrastructures ${ }^{18}$.

From an average contribution of $4 \%$ to world transport fuel production in 2014 , biofuels are projected to rise modestly in their contribution to liquid fuels, reaching $4.3 \%$ in 2020 . Investments in biofuel research and development by the major energy companies is expected to decline marginally, in the near to medium term, as a result of the recent slump in global oil prices ${ }^{19}$. Table 1 shows the major ethanol biorefineries in Europe with an installed capacity greater than 100 million Litres per year of ethanol production. The biorefineries with feedstock variability shown will place additional demands on operator capabilities.

The vision for today's biorefinery is the development of a bioprocessing facility that transforms biomass into a number of products using tested catalytic and biochemical routes, at a sufficiently large scale that takes advantage of the processing efficiencies and improved economics inherent in today's petroleum refineries. The concept can be envisaged as the petroleum refinery modified to process a different feedstock, to make high value products using some of the unit operations in a petroleum refinery, and some additional unit operations ${ }^{16}$.

A comprehensive classification of biorefineries based on the entire process value chain from feedstock to final products has been developed by the IEA Bioenergy Task 4216 . The classification is based on four main pillars: feedstocks, intermediates, conversion processes and final processes. The conversion processes are grouped into four main classes, namely: biochemical (e.g. fermentation and enzymatic hydrolysis), thermochemical (e.g. pyrolysis and gasification), chemical (e.g. acid hydrolysis), and mechanical conversion processes (e.g. milling and pressing). Figure 1 is a schematic diagram of the different routes from biomass to final products in different biorefinery configurations (adapted from Jungmeier et al. ${ }^{20}$ ). There is increasing focus on the use of low value feedstocks that do not compete with food crops and land used for arable agriculture. In order to create such zerowaste biorefineries, it is important to develop zero waste and highly efficient processes for the collection and processing of various biomass derived feedstocks ${ }^{21}$. 
Table 1: Major Biorefineries in Europe

\begin{tabular}{|c|c|c|c|c|}
\hline Plant & $\begin{array}{l}\text { Nameplate Capacity } \\
\text { [million Litres / year] }\end{array}$ & Location & Main Feedstock & Year Established \\
\hline $\begin{array}{l}\text { Abengoa Bioenergy } \\
\text { France S.A. }\end{array}$ & 250 & Lacq, France & Corn and low quality vegetable alcohols & 2005 \\
\hline $\begin{array}{l}\text { Ecocarburantes } \\
\text { Españoles }\end{array}$ & 151 & $\begin{array}{l}\text { Cartagena, } \\
\text { Spain }\end{array}$ & $\begin{array}{l}\text { Flexible (grains - barley, wheat, Cereal straw, agricultural and } \\
\text { forestry waste, energy crops, sugar beets) }\end{array}$ & 1996 \\
\hline $\begin{array}{l}\text { Biocarburantes Castilla y } \\
\text { León }\end{array}$ & 200 & $\begin{array}{l}\text { Salamanca, } \\
\text { Spain }\end{array}$ & $\begin{array}{l}\text { Flexible (grains - barley, wheat, Cereal straw, agricultural and } \\
\text { forestry waste, energy crops, sugar beets) }\end{array}$ & 2000 \\
\hline $\begin{array}{l}\text { Abengoa Bioenergy } \\
\text { Netherlands }\end{array}$ & 480 & $\begin{array}{l}\text { Rotterdam, } \\
\text { Netherlands }\end{array}$ & Flexible grains (wheat, barley, corn and sorghum) & $\begin{array}{l}2006, \text { became } \\
\text { operational in } 2010\end{array}$ \\
\hline Tereos Origny & 330 & $\begin{array}{l}\text { ORIGNY } \\
\text { SAINTE } \\
\text { BENOITE, } \\
\text { France }\end{array}$ & 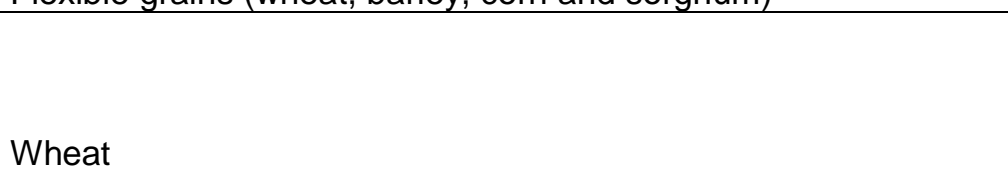 & 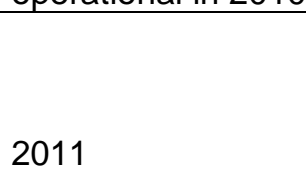 \\
\hline Tereos Lillebonne & 500 & $\begin{array}{l}\text { Lillebonne, } \\
\text { France }\end{array}$ & Wheat & 2005 \\
\hline $\begin{array}{l}\text { CropEnergies Bioethanol } \\
\text { GmbH }\end{array}$ & 400 & $\begin{array}{l}\text { Zeitz, } \\
\text { Germany }\end{array}$ & Flexible (grains - wheat, maize, barley and triticale, sugar beets) & 1977 \\
\hline $\begin{array}{l}\text { CropEnergies Bioethanol } \\
\text { GmbH (Ensus) }\end{array}$ & 400 & Wilton, UK & Feed Wheat & 2009 \\
\hline $\begin{array}{l}\text { CropEnergies Bioethanol } \\
\text { GmbH (Biowanze) }\end{array}$ & 300 & $\begin{array}{l}\text { Wanze, } \\
\text { Belgium }\end{array}$ & Wheat and sugar beets & $\begin{array}{l}2006, \text { became } \\
\text { operational in } 2011\end{array}$ \\
\hline PROKON NORD & 120 & $\begin{array}{l}\text { Stade,Lower } \\
\text { Saxony, } \\
\text { Germany }\end{array}$ & Wheat & $\begin{array}{l}2005 \text {, became } \\
\text { operational in } 2008\end{array}$ \\
\hline Verbio Biofuels & 260 & $\begin{array}{l}\text { Schwedt, } \\
\text { Germany }\end{array}$ & Rye (non-food/feed material) & 2000 \\
\hline IMA BioFuels & 110 & Trapani, Italy & Wine by-products (grape marc and wine-lees & 1982 \\
\hline Vivergo Biofuels & 420 & Hull, UK & Feed Wheat & $\begin{array}{l}2006, \text { became } \\
\text { operational in } 2012\end{array}$ \\
\hline Pannonia Ethanol & 450 & $\begin{array}{l}\text { Dunaföldvár, } \\
\text { Hungary }\end{array}$ & Corn & $\begin{array}{l}2009 \text {, became } \\
\text { operational in } 2016\end{array}$ \\
\hline Agrana Bioethanol GmbH & 210 & $\begin{array}{l}\text { Pischelsdorf, } \\
\text { Austria }\end{array}$ & Mainly Wheat and Corn & 2013 \\
\hline Alco Bio Fuel N.V. & 150 & Gent, Belgium & Feed wheat and corn & $\begin{array}{l}2005, \text { became } \\
\text { operational in } 2008\end{array}$ \\
\hline ENVIRAL & 145 & $\begin{array}{l}\text { Leopoldov, } \\
\text { Slovakia }\end{array}$ & Corn & $\begin{array}{l}2004, \text { became } \\
\text { operational in } 2007\end{array}$ \\
\hline
\end{tabular}



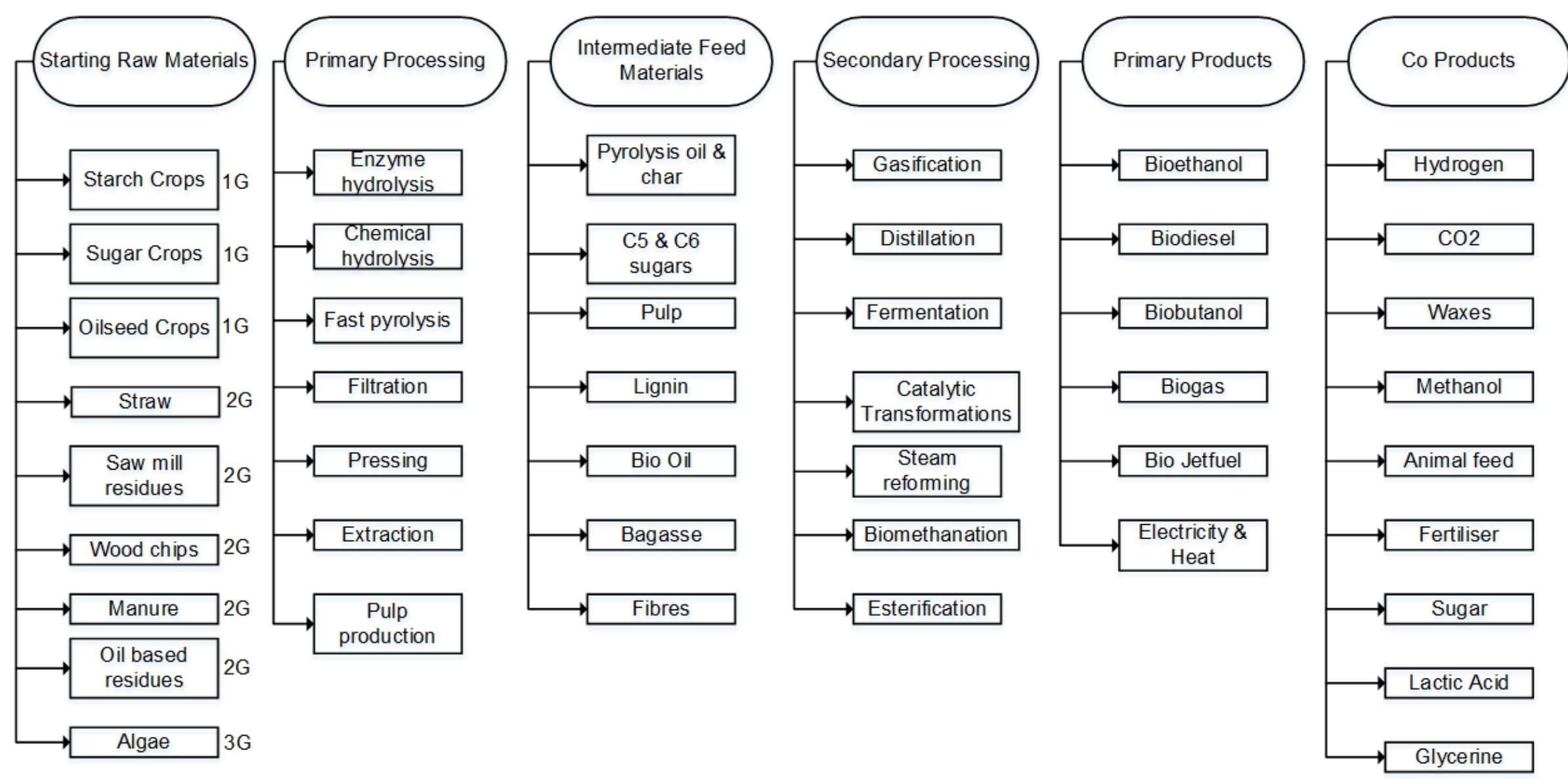

1G: First Generation Biofuel

2G: Second Generation Biofuel

3G: Third Generation Biofuel

Figure 1: Routes from biomass to final products in different biorefinery configurations (Adapted from Jungmeier et al ${ }^{18}$ ) 


\section{OTS Design Frameworks}

In the context of this review, a framework is defined as an essential supporting structure underlying a system, concept, or object (www.oxforddictionaries.com). According to the US Accreditation Board for Engineering and Technology ( $\mathrm{ABET}$ ), engineering design is the process of deriving a system, component, or process to meet desired needs. From the above, an OTS design framework is construed to mean those supporting structures that underpin the process of developing an operator training simulator in order to meet clearly stated objectives. A user centred design approach has been adopted by several investigators in the design of operator training simulators. Established design frameworks in other disciplines are often adapted for the design of training simulators for biotechnological processes.

One of the earliest papers to discuss the potential for applying OTS design frameworks used in chemical engineering to bioprocess technology is that of Hass and his co-workers 22 . In this paper, the authors argue that the useful life of process models developed for engineering applications during the initial design stages of a chemical or biochemical process, can be extended by using such process models as operator training systems. This approach would deliver much higher returns from the huge initial investment of capital and time in the development of such models. The synergies in the usefulness of process models for both process optimisation and operator training is facilitated by the fact that the requirements for developing a process model for process optimisation is similar to those required for developing an OTS, apart from the additional requirement of creating a graphical user interface for operator training.

In this pioneering work, Hass and his co-workers describe the development of a coding framework that integrates process model development and optimisation (including parameter estimation and verification) and a commercial process control/visualisation system. Extended use of the process model beyond design work for operator training is done by importing the process model into a process control system and creating a realistic graphical user interface, similar to what an operator would see in an industrial process control system. Model development is carried out in C-eStIM ${ }^{22}$ and integrated with the process control software WinErs ${ }^{23}$ to form an operator training simulator.

A user-centred approach in the design of training simulators for biotechnological processes has been reported ${ }^{9}$. In their contribution to conceptual design methods in bioprocess engineering, Mandenius and Bjorkman describe a design approach that adapts design methods from electrical and mechanical engineering to offer a structured approach for designing biotech products. Such an approach involves two steps, namely: generating conceptual solutions to the design problem; and analysing the structures and functions of alternative solutions to arrive at the option that best meets the target user requirements. Mandenius and Bjorkman present two design approaches for dealing with the inherent complexities involved in designing biotechnological products and processes: The Hubka-Eder model ${ }^{24}$ and the UlrichEppinger model ${ }^{25}$.

The Hubka-Eder design approach begins with a description of the transformations that will be carried out by the system by consuming input elements and creating outputs. During the transformation process, a number of different systems are required. These include technical, human, information, management, and control systems. Although the Hubka-Eder model was originally described for designing mechanical devices such as coffee machines and automobiles, Mandenius and Bjorkman argue that the methods described can be adapted by bioengineers to design processes and products that include complex biological interactions. This methodology provides a useful approach for managing the inherent complexities of designing a biorefinery OTS.

In the Ulrich-Eppinger model, the design process begins with detailed identification and specification of the customer's needs. With the needs defined and specified, conceptual design solutions that satisfy the stated needs are identified. The solutions are evaluated and scored based on how well they meet the target customer needs earlier defined. In biotechnology, some of these user needs can include product purity, bioactivity, and yield. Mandenius and Bjorkman provide detailed applications of the conceptual design methodology in the design of a bioreactor, an artificial liver device, and in stem cell manufacture.

The above models were applied by Gerlach et. al..$^{7}$ in the conceptual design of an operator training simulator for a commercial bioethanol plant, where five to ten process operators are responsible for plant operation and process control. The bioreactors studied ranged in size from $30-280 \mathrm{~m}^{3}$. An important element of this design effort was the participation of plant management and operators in the early stages of the design process. Training objectives were clearly identified and specified targets were set to measure 
when these objectives are met. A number of OTS design alternatives were generated and a ranking method used to select those design options best suited to meeting the defined training objectives.

A design approach commonly used to translate customer requirements into the necessary technical specifications for product design is the quality function deployment (QFD) ${ }^{26}$. QFD was originally conceived as a means for both quality control and improvement in Japanese manufacturing enterprises. The primary uses of QFD are for product development, quality management and customer needs analysis. However, Chan and Wu acknowledge that the potential fields of application of QFD are numerous, including systems engineering. QFD provides a structured methodology for integrating customer requirements into engineering specifications and to production process variables, and thus enhance production planning ${ }^{27}$. A similar method for product quality assurance used in the development of biopharmaceutical products is Quality by Design (QbD). QbD was first conceived by Juran ${ }^{28}$ and first applied to biopharmaceuticals by the US Food and Drug Administration's (FDA) Office of Pharmaceutical Science ${ }^{29}$.

In addition to the QFD methodology, the failure modes and effects analysis (FMEA) is used to provide assurance of the reliability and quality of a product or process during the early development stages ${ }^{30}$. The method allows designers to establish a product's potential failure modes and recommend actions that can be taken to mitigate them. This early detection and correction of potential failure modes prevents costly and complicated correction processes at later stages in the design process.

The integration of QFD and FMEA methodologies as part of managing quality and reliability during a product's life cycle was first proposed by Ginn and his co-workers ${ }^{31}$. In this integrated approach, QFD is used in the early stages of product or process development to elucidate customer requirements and match these to product specifications thereby ensuring positive customer satisfaction, while FMEA is typically used as a problem prevention tool, to improve identified customer requirements and prevent customer dissatisfaction. Thus, Ginn et al. argue that the full capabilities of both the QFD and FMEA are not fully utilised when they are used in isolation at different stages of the product development lifecycle. Similarly, $\operatorname{Tan}^{32}$ argued that in order to increase built-in reliability during product design, the QFD methodology can be used to incorporate a customer focus to the FMEA process, thus maximising its effectiveness.

\section{Tools and methods for OTS design}

An operator training simulator essentially comprises process models and a graphical user interface that allows operators to interact with the process. Process models provide detailed mathematical descriptions of the biological and physicochemical phenomena under consideration. These mathematical models are coupled to the graphical user interface using automation and control software that enable an operator to make changes to and monitor the process. Given the huge investment of time and resources required to develop an OTS, it is important that the methods and tools used for both mathematical model development and operator interface design provide a seamless environment for the developer. According to Hass ${ }^{1}$, desirable characteristics of a functionally useful OTS include realistic simulation of the biological, physical and chemical processes under investigation; accurate representation of automation and control actions; and graphical user interfaces with a similar "look and feel" to that of the plant being modelled.

Mathematical models used in OTS development are classified broadly as mechanistic or empirical models. In this context, a model refers to a mathematical representation of certain aspects of a real world object or phenomenon ${ }^{33}$. Empirical models use a set of experimental data to explain observed phenomena by fitting parameters based on the available dataset. No attempt is made to incorporate the underlying biological or chemical phenomena that gave rise to the experimental data. Regression models are examples of empirical models. Mechanistic models, on the other hand, are based on first principles and seek to explain experimental observations based on the underlying biological, chemical and physical mechanisms that occur in the system. While huge modelling efforts are required to understand and represent mechanistic models and obtain useful model parameters, they offer excellent predictive capabilities beyond the original experimental conditions used for model development. Empirical models do not offer such predictive capabilities.

Mathematical modelling for a biorefinery OTS involves a number of key steps. The first step is the definition of the biorefinery under consideration using appropriate diagrams and charts. The Process Flow Diagram and Piping and Instrumentation Diagram are excellent starting points for biorefinery system definition. Ideally, a verbal process description of the biorefinery, expected modelling targets including levels of model fidelity, and desirable training outcomes are specified at this stage. Following system description, appropriate mathematical models that sufficiently describe the physical, biological, chemical processes in 
the system are formulated based on literature searches. The final stages of biorefinery OTS development include model implementation using appropriate tools; model parameterisation and finally model validation using experimental data ${ }^{1}$.

Some of the tools used for biorefinery OTS model development include commercially available software such as AspenTech tools (Aspen Plus, Aspen Dynamics and Aspen OTS Framework) and Unisim. Although such sequential modelling tools are readily available and easy to use, they do not offer the flexibility and adaptability required to model all aspects of bioprocesses as they were originally designed for modelling chemical processes. The presence of a large number of model libraries for common unit operations makes it easy to model many traditional chemical processes. With the increasing focus on biorenewable energy development, significant effort has been invested in recent years in the development of model libraries for bioprocess unit operations. Software systems that allow for parameter estimation and the solution of algebraic and differential equations offer a user friendly and adaptable environment for model development and implementation for a biorefinery OTS. C-eStIM is one such tool that is based on the $C_{++}$programming language ${ }^{7}$. Several authors have reported the integration of C-eStIM with the commercial process control and automation software WinErs, thus providing an easy-to-use environment for mathematical model development, solution of algebraic and differential equations, model parameterisation, and the development of graphical user interfaces that closely resemble those found in a biorefinery distributed control system (DCS) $5,7,22,34$. Such emulation simulators provide user interfaces that closely resemble the DCS interface provided by commercial DCS suppliers such as Honeywell, Foxboro, and Siemens. Table 2 shows the major OTS vendors for the process industries and the key features of each proprietary simulator offering. 
Table 2: Major OTS Vendors for the Process industries.

\begin{tabular}{|c|c|c|}
\hline OTS Vendor & Proprietary Simulator Name & Key Features \\
\hline \multirow[t]{2}{*}{ Invensys } & $\begin{array}{l}\text { SimSci Operator Training } \\
\text { Simulators }\end{array}$ & $\begin{array}{l}\text { Uses Schneider Electric's OTS solution; } \\
\text { DYNSIM model for dynamic process model development. }\end{array}$ \\
\hline & $\begin{array}{l}\text { EYESIM Immersive Virtual } \\
\text { Reality Training System }\end{array}$ & $\begin{array}{l}\text { Similar to SimSci; } \\
\text { Links control room operators to field operators and maintenance operators by means of a high-fidelity 3D } \\
\text { process simulation and virtual walkthrough plant environment. }\end{array}$ \\
\hline Genesis Oil \& Gas & gOTS Suite & $\begin{array}{l}\text { Comprises gOPC, glnstructor, and gEmulator; } \\
\text { Dynamic process models developed using Hysys dynamic or Unisim dynamic. }\end{array}$ \\
\hline Yokogawa & $\begin{array}{l}\text { OmegaLand OTS \& MIRROR } \\
\text { PLANT }\end{array}$ & $\begin{array}{l}\text { Serves Oil and Gas, Refining, Petrochemical, Chemical and Power industries; } \\
\text { MIRROR PLANT constantly synchronizes with the plant control system; } \\
\text { Able to predict plant internal states and plant responses, contributing to optimized plant operations. }\end{array}$ \\
\hline Honeywell & $\begin{array}{l}\text { UniSim Competency Training } \\
\text { Simulators }\end{array}$ & $\begin{array}{l}\text { Customizable framework for a structured operator competency management system; } \\
\text { Provides a repository for domain knowledge and experiences to teach and evaluate 'what if' reflexes and } \\
\text { diagnostic abilities for improved decision-making; } \\
\text { Accelerates knowledge transfer by consolidating a range of typical and emergency training experiences } \\
\text { into a concise curriculum; } \\
\text { Interactive, navigable, panoramic 2D field operator training environment based on high-resolution } \\
\text { photographs of the facility; } \\
\text { Connectivity and integration to 3D immersive virtual field operator training and visualization } \\
\text { environments. }\end{array}$ \\
\hline Emerson & DeltaV OTS & Process specific dynamic model; \\
\hline
\end{tabular}




\begin{tabular}{|c|c|c|}
\hline OTS Vendor & Proprietary Simulator Name & Key Features \\
\hline & & Identical Operator Graphics as 'Live' DCS \\
\hline OTS B.V & OTS Expert Suite & $\begin{array}{l}\text { Exact copy of existing DCS; } \\
\text { Can connect to any DCS software (Emerson DeltaV, Yokogawa Centum CS 3000, Honeywell Experion, } \\
\text { Schneider Electric Foxboro, Siemens PCS7, etc.); } \\
\text { Touchscreen exactly identical to the real plant. }\end{array}$ \\
\hline DuPont & TMODS & $\begin{array}{l}\text { Fully customized to match plant configuration, conditions, compositions, control schemes, safety } \\
\text { interlocks and user interfaces. }\end{array}$ \\
\hline Protomation & Protomation OTS & $\begin{array}{l}\text { Real-time dynamic model that covers the complete operating window; } \\
\text { Allows accurate simulation and training in the entire operating range of the plant (from start-up conditions } \\
\text { up to normal operation and upset conditions). }\end{array}$ \\
\hline $\begin{array}{l}\text { Ingenious Inc } \\
\text { (Woodgroup) }\end{array}$ & ProDyn & $\begin{array}{l}\text { Offers off-the-shelf and customer-specific solutions; } \\
\text { Operator training and learning systems, abnormal situation management, and process troubleshooting; } \\
\text { Allows resolving unstable operations, revamp studies; What-if studies, DCS/Logic testing, equipment } \\
\text { evaluation; } \\
\text { Can be used to develop and test plant procedures; } \\
\text { Cloud Deployment - allows the user to connect to the model as an operator from any location by simply } \\
\text { having an Internet connection }\end{array}$ \\
\hline TSC Simulation & Several OTS Suites & $\begin{array}{l}\text { Runs on standard PCs using Windows with Ethernet and IP connectivity; } \\
\text { Uses industry proven accurate mathematical algorithms for modelling; } \\
\text { No third party licensing costs, TSC provides lifetime licensing; } \\
\text { Runs on individual PCs, networked classroom, or in our Virtual Control Room; }\end{array}$ \\
\hline
\end{tabular}




\begin{tabular}{|c|c|c|}
\hline OTS Vendor & Proprietary Simulator Name & Key Features \\
\hline $\begin{array}{l}\text { RSI (IFP Energies } \\
\text { Nouvelles Group) }\end{array}$ & IndissPlus & $\begin{array}{l}\text { Models based on first principles of chemical engineering with rigorous thermodynamics calculation and } \\
\text { physical component properties database; } \\
\text { Can accurately represent plant start-up and shutdown, in addition to a variety of design and abnormal } \\
\text { operating conditions; } \\
\text { Can be run locally, on a network or remotely via a web browser for web-based e-Learning; } \\
\text { Sharable Content Object Reference Model (SCORM) compliant and can easily be integrated with } \\
\text { Learning Management Systems (LMS) }\end{array}$ \\
\hline AspenTech & Aspen OTS Framework & $\begin{array}{l}\text { Dynamic models developed using Aspen HYSYS Dynamics }{ }^{\mathrm{TM}} \text { and Aspen Plus Dynamics }{ }^{\mathrm{TM}} \text {; } \\
\text { Simulator Executive Framework provides a configuration mode used to set up all of the required data } \\
\text { links between the dynamic model(s) and the other components of an OTS application; } \\
\text { Data Communication Links handle the exchange of data and commands and are based on } \\
\text { OPC technology; } \\
\text { Can translate and emulate the plant's actual control strategies into modules that } \\
\text { can be used within the OTS system without the need to buy a replicate DCS system, thus } \\
\text { reducing the OTS cost significantly; } \\
\text { User Interfaces support different views of the application for operators, engineers, and } \\
\text { training instructors; }\end{array}$ \\
\hline Konsberg & K-Spice $\AA^{\circledR}$ Train & 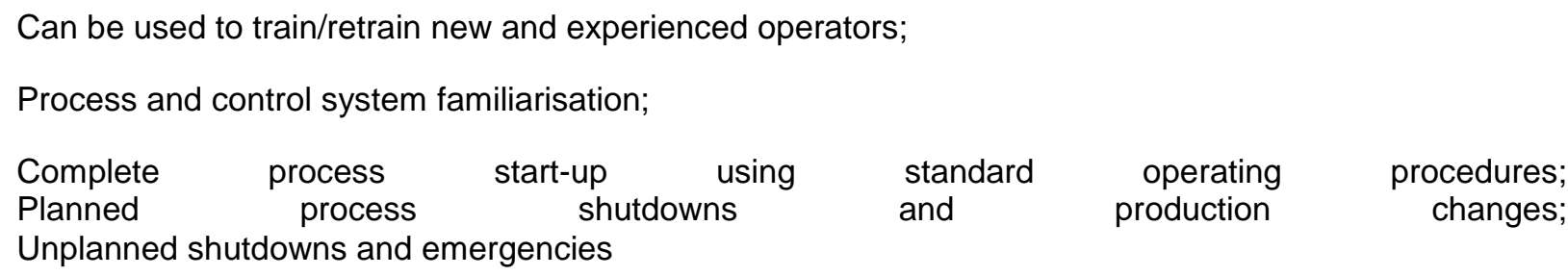 \\
\hline
\end{tabular}




\begin{tabular}{|c|c|c|}
\hline OTS Vendor & Proprietary Simulator Name & Key Features \\
\hline $\begin{array}{l}\text { SIMULATION } \\
\text { SOLUTIONS, INC. }\end{array}$ & Several OTS Suites & $\begin{array}{l}\text { Includes both a DCS component and a Virtual Reality Outside Operator console; } \\
\text { Actions performed in the Outside Operator (Opening of Valves, Pumps, Controllers) are reflected in real } \\
\text { time on the DCS schematics, and vice versa. }\end{array}$ \\
\hline Simtronics & Several OTS Suites & $\begin{array}{l}\text { Intuitive, high-fidelity simulators; } \\
\text { Includes performance evaluation tools, fault capabilities, and integrated equipment tutorials. }\end{array}$ \\
\hline Inprocess & Several OTS Suites & $\begin{array}{l}\text { Helps reduce risk of operational incidents and start-up time, and environmental concerns; } \\
\text { Verify Distributed Control Systems (DCS) and Safety Instrumented Systems (SIS); } \\
\text { Increases operator awareness and skills; } \\
\text { De-bottleneck units and processes }\end{array}$ \\
\hline Siemens & Operator Training System & $\begin{array}{l}\text { Based on a dynamic modelling of the plant; } \\
\text { Tailor-made scenarios; } \\
\text { Flexible modelling - the process can be emulated as a whole or in parts. }\end{array}$ \\
\hline $\begin{array}{l}\text { Ingenieurbüro Dr.-Ing. } \\
\text { Schoop GmbH }\end{array}$ & C-eStIM/WinErs & $\begin{array}{l}\text { Modular process automation system; } \\
\text { Provides a flexible, process control and simulation system suitable for industrial, didactical and research } \\
\text { applications; } \\
\text { Complete process monitoring and operation via user edited graphical interfaces; } \\
\text { Individually adjustable storing methods with a storage period from 1ms; } \\
\text { Simple graphical editing of controls and simulations via block structures, logic plans and GRAFCET with } \\
\text { no prior programming knowledge required; } \\
\text { Set up sequence control with GRAFCET according to DIN EN 60848; } \\
\text { Allows multi user administration - administration of users with hierarchical rights; }\end{array}$ \\
\hline
\end{tabular}




\begin{tabular}{|l|l|l|}
\hline OTS Vendor & Proprietary Simulator Name & Key Features \\
\hline NovaTech & $\begin{array}{l}\text { NovaTech Ethanol Training } \\
\text { Simulator, D/3 DCS }\end{array}$ & $\begin{array}{l}\text { Allow breweries, biofuels facilities, and other process plants to develop real-to-life plant simulations; } \\
\text { Training on complex process control techniques and correcting behavioural patterns; } \\
\text { Recipe driven state based control and batch management and control; } \\
\text { Alarm management and data historian capabilities; } \\
\text { Trend visualization, process analytics and control Loop performance monitoring and optimization; } \\
\text { Regulatory compliance and validation; } \\
\text { System hardware and custom I/O cabinet design. }\end{array}$ \\
\hline
\end{tabular}




\section{OTS Design and Use in Biotechnology}

A number of researchers have investigated the applications of OTSs in small scale bioprocessing operations $^{35,36}$. The general premise of these simulators is that model-based operator training simulators can be used to improve the educational experience of students and enhance the competence of plant operators in running complex bioprocesses. A summary of the main research findings on OTS design and deployment in biotechnological processes is presented in Table 3, while Figures 2 to 4 are examples of OTS graphical user interfaces developed using different software tools.

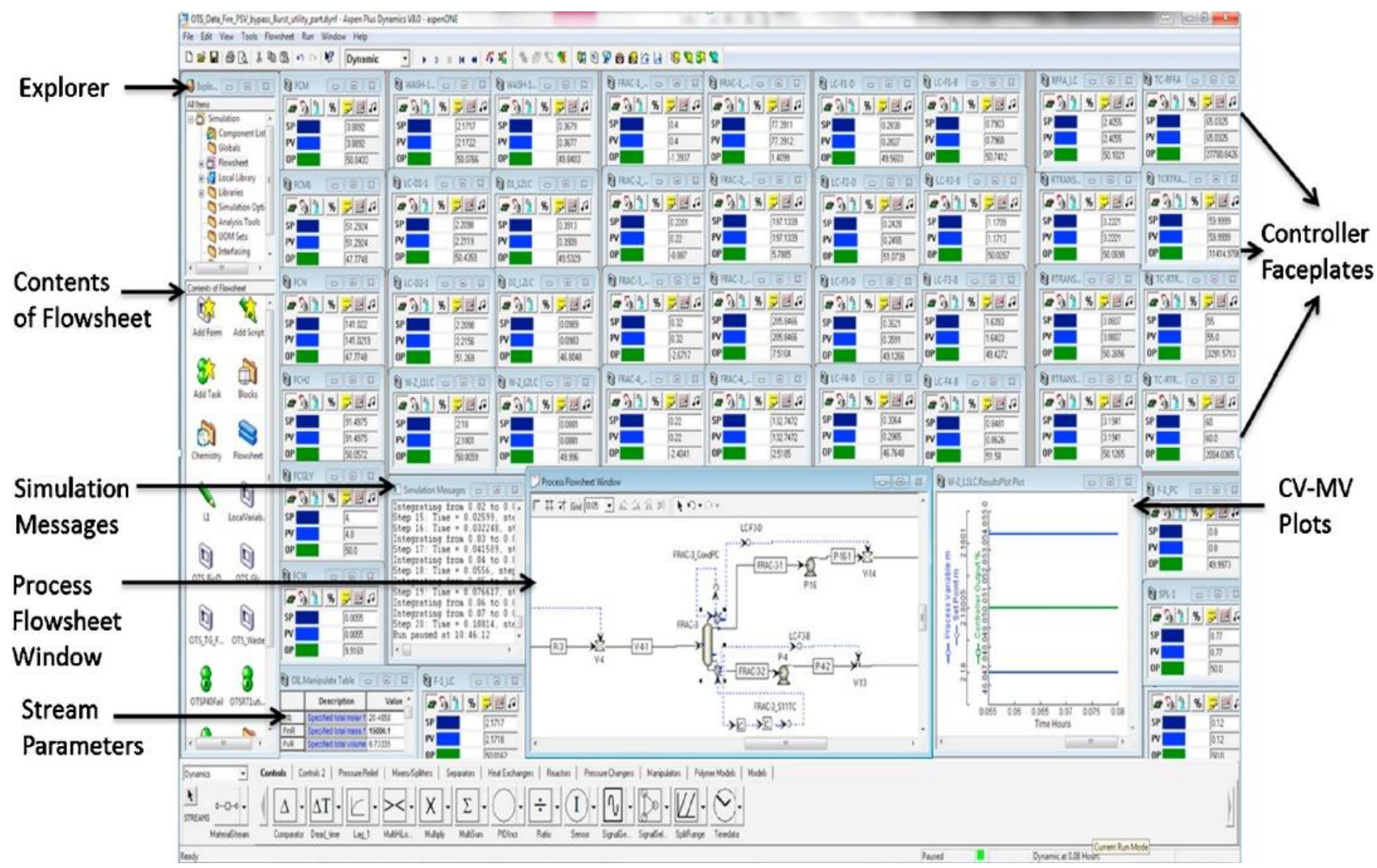

Figure 2: Biorefinery OTS developed using Aspen OTS Framework ${ }^{37}$ 
Table 3: Main research findings on OTS applications in bioprocessing.

\begin{tabular}{|c|c|c|c|c|c|}
\hline Publication & Field of application & Bioprocess scale & Development tools & Validation method & OTS fidelity \\
\hline Ahmad et al. ${ }^{37}$ & $\begin{array}{l}\text { Conceptual design of 2-step } \\
\text { biodiesel synthesis process }\end{array}$ & $\begin{array}{l}\text { Theoretical } 120,000 \text { tonnes per } \\
\text { annum capacity biorefinery }\end{array}$ & $\begin{array}{l}\text { Aspen Plus Dynamics } \\
\text { Aspen OTS Framework }\end{array}$ & None & $\begin{array}{l}\text { Theoretical construct. No } \\
\text { actual plant to mimic. Aspen } \\
\text { Plus sequential modelling } \\
\text { tools provide reasonable } \\
\text { model accuracy, although not } \\
\text { validated in this study. }\end{array}$ \\
\hline Balaton et al. ${ }^{38}$ & $\begin{array}{l}\text { Batch reactor hydrodynamic } \\
\text { and thermal behaviour } \\
\text { parameterisation }\end{array}$ & $\begin{array}{l}30 \mathrm{~L} \text { jacketed batch reactor in Lab. } \\
\text { Pilot plant. }\end{array}$ & Unisim Design & $\begin{array}{l}\text { Simulation temperature } \\
\text { profiles compared with lab. } \\
\text { Reactor temperature } \\
\text { measurements }\end{array}$ & $\begin{array}{l}\text { Medium: reasonable } \\
\text { agreement between simulation } \\
\text { and experimental results. }\end{array}$ \\
\hline Blesgen \& Hass ${ }^{5}$ & Anaerobic biogas production & $\begin{array}{l}10 \mathrm{~L} \text { lab reactor (used for } \\
\text { parameterization and user interface } \\
\text { design) }\end{array}$ & $\begin{array}{l}\text { FORTRAN (biological and } \\
\text { physicochemical submodels) } \\
\text { WinErs (reactor and plant submodels, } \\
\text { plus automation, process control and } \\
\text { graphical user interface). }\end{array}$ & $\begin{array}{l}\text { Experimental data from } \\
\text { literature validated with } \\
\text { simulation runs }\end{array}$ & $\begin{array}{l}\text { Kinetics sub-model: Medium } \\
\text { fidelity } \\
\text { Automation and process } \\
\text { control sub-models: Medium } \\
\text { fidelity } \\
\text { Graphical user interphase: } \\
\text { Medium fidelity }\end{array}$ \\
\hline Gerlach et al. ${ }^{34}$ & $\begin{array}{l}\text { Bioethanol production from } S \text {. } \\
\text { cerevisiae and Green } \\
\text { Fluorescence Protein } \\
\text { production using E. coli. }\end{array}$ & $\begin{array}{l}15 \mathrm{~L} \text { stirred Bioreactor for } \\
\text { Bioethanol production and } 6 \mathrm{~L} \text { fed- } \\
\text { batch bioreactor for GFP production }\end{array}$ & $\begin{array}{l}\text { Biological and physicochemical } \\
\text { models integrated into WinErs as } \\
\text { Dynamic Link Libraries (DLLs) }\end{array}$ & $\begin{array}{l}\text { Substrate consumption, } \\
\text { product formation and } \\
\text { biomass yields were } \\
\text { compared between lab } \\
\text { reactor and simulator runs }\end{array}$ & $\begin{array}{l}\text { Kinetics sub-model: High } \\
\text { fidelity } \\
\text { Automation and process } \\
\text { control sub-models: Medium } \\
\text { fidelity } \\
\text { Graphical user interphase: } \\
\text { Medium fidelity }\end{array}$ \\
\hline Gerlach et al. ${ }^{7}$ & $\begin{array}{l}\text { Large scale commercial } \\
\text { bioethanol process }\end{array}$ & $\begin{array}{l}\text { Reactors ranging in size from } \\
30,000 \mathrm{~L} \text { to } 280,000 \mathrm{~L}\end{array}$ & $\begin{array}{l}\text { Process models written in C++ were } \\
\text { implemented as Dynamic Link } \\
\text { Libraries (DLLs) in WinErs }\end{array}$ & $\begin{array}{l}\text { Model validation not } \\
\text { presented }\end{array}$ & $\begin{array}{l}\text { Automation and process } \\
\text { control sub-models: Medium } \\
\text { fidelity } \\
\text { Graphical user interphase: } \\
\text { Medium fidelity }\end{array}$ \\
\hline Gerlach et al. ${ }^{39}$ & $\begin{array}{l}\text { Integrated cultivation and } \\
\text { homogenisation for } \\
\text { recombinant protein } \\
\text { production }\end{array}$ & $\begin{array}{l}10 \mathrm{~L} \text { bioreactor for cell cultivation, } \\
\text { with maximum throughputs of } 45 \mathrm{~L} / \mathrm{h} \\
\text { in high pressure homogeniser. }\end{array}$ & $\begin{array}{l}\text { Process models written in C++ were } \\
\text { implemented as Dynamic Link } \\
\text { Libraries (DLLs) in WinErs }\end{array}$ & $\begin{array}{l}\text { Substrate consumption, } \\
\text { product formation and } \\
\text { biomass yields were } \\
\text { compared between lab } \\
\text { reactor and simulator runs }\end{array}$ & $\begin{array}{l}\text { Kinetics sub-model: High } \\
\text { fidelity } \\
\text { Automation and process } \\
\text { control sub-models: Medium } \\
\text { fidelity }\end{array}$ \\
\hline
\end{tabular}




\begin{tabular}{|c|c|c|c|c|c|}
\hline Publication & Field of application & Bioprocess scale & Development tools & Validation method & OTS fidelity \\
\hline & & & & & $\begin{array}{l}\text { Graphical user interphase: } \\
\text { Medium fidelity }\end{array}$ \\
\hline Hass et al. ${ }^{22}$ & $\begin{array}{l}\text { Describes the development of } \\
\text { a coding framework combined } \\
\text { with a commercial process } \\
\text { control software for rapid } \\
\text { process model development in } \\
\text { chemical and biochemical } \\
\text { engineering }\end{array}$ & Applies to all scales & $\begin{array}{l}\text { eStIM coding framework used for } \\
\text { biological and process model } \\
\text { development and WinErs is used for } \\
\text { automation and process control }\end{array}$ & $\begin{array}{l}\text { Experimental data from } \\
\text { yeast production } \\
\text { compared with simulation } \\
\text { results }\end{array}$ & $\begin{array}{l}\text { Kinetics sub-model: High } \\
\text { fidelity } \\
\text { Automation and process } \\
\text { control sub-models: Medium } \\
\text { fidelity } \\
\text { Graphical user interphase: } \\
\text { Medium fidelity }\end{array}$ \\
\hline Hass et al. ${ }^{35}$ & $\begin{array}{l}\text { Whole plant model comprising } \\
\text { bioethanol production, } \\
\text { distillation and biomass power } \\
\text { plant }\end{array}$ & $\begin{array}{l}10 \mathrm{~L} \text { lab fermenter used for } \\
\text { fermentation model experiments }\end{array}$ & $\begin{array}{l}\text { Biological models written in Fortran } \\
\text { and compiled with eStIM were } \\
\text { implemented as DLLs in WinErs. }\end{array}$ & $\begin{array}{l}\text { Lab fermenter and } \\
\text { distillation runs were used } \\
\text { to validate simulator runs. }\end{array}$ & $\begin{array}{l}\text { Kinetics sub-model: High } \\
\text { fidelity } \\
\text { Automation and process } \\
\text { control sub-models: Medium } \\
\text { fidelity } \\
\text { Graphical user interphase: } \\
\text { Medium fidelity }\end{array}$ \\
\hline Hass et al. ${ }^{40}$ & $\begin{array}{l}\text { Bioethanol production, } \\
\text { crossflow filtration and } \\
\text { rectification column }\end{array}$ & $\begin{array}{l}15 \mathrm{~L} \text { lab. bioreactors used for } \\
\text { ethanol production }\end{array}$ & $\begin{array}{l}\text { Process models written in } \mathrm{C}++ \text { were } \\
\text { implemented as Dynamic Link } \\
\text { Libraries (DLLs) in WinErs. GRAFCET } \\
\text { used for developing automation } \\
\text { sequences. }\end{array}$ & $\begin{array}{l}\text { Lab fermenter, membrane } \\
\text { filtration unit and } \\
\text { distillation runs were used } \\
\text { to validate simulator runs. }\end{array}$ & $\begin{array}{l}\text { Kinetics sub-model: High } \\
\text { fidelity } \\
\text { Automation and process } \\
\text { control sub-models: Medium } \\
\text { fidelity } \\
\text { Graphical user interphase: } \\
\text { Medium fidelity }\end{array}$ \\
\hline $\begin{array}{l}\text { González Hernández et } \\
\text { al. }{ }^{6}\end{array}$ & $\begin{array}{l}\text { Integrated wastewater } \\
\text { biodegradation and membrane } \\
\text { filtration in a submerged } \\
\text { membrane bioreactor (SMBR) }\end{array}$ & $10 \mathrm{~L}$ aerobic reactor & $\begin{array}{l}\text { Biological model written and } \\
\text { implemented in Pascal, while process } \\
\text { automation and GUI was developed } \\
\text { using Delphi } 2009\end{array}$ & $\begin{array}{l}\text { Experimental data from } \\
\text { literature validated with } \\
\text { simulation runs }\end{array}$ & $\begin{array}{l}\text { Kinetics sub-model: Low } \\
\text { fidelity } \\
\text { Automation and process } \\
\text { control sub-models: Medium } \\
\text { fidelity } \\
\text { Graphical user interphase: } \\
\text { Medium fidelity }\end{array}$ \\
\hline
\end{tabular}


One of the earliest attempts to develop a training simulator for complex biorefineries is given by Hass and his co-workers ${ }^{35}$. Their work presented a full biorefinery model comprising three single unit simulators: a bioethanol fermentation model, a distillation model, and a biomass power plant model. Dynamic mathematical models of the three unit operations were developed by Hass and his co-workers and implemented into a FORTRAN source code, which was executed in the eStIM software package. The process control software WinErs was used to incorporate the process control scheme in the simulation model. Finally, a graphical user interface (GUI) which allowed operators to interact with process equipment was included to obtain a full biorefinery model.

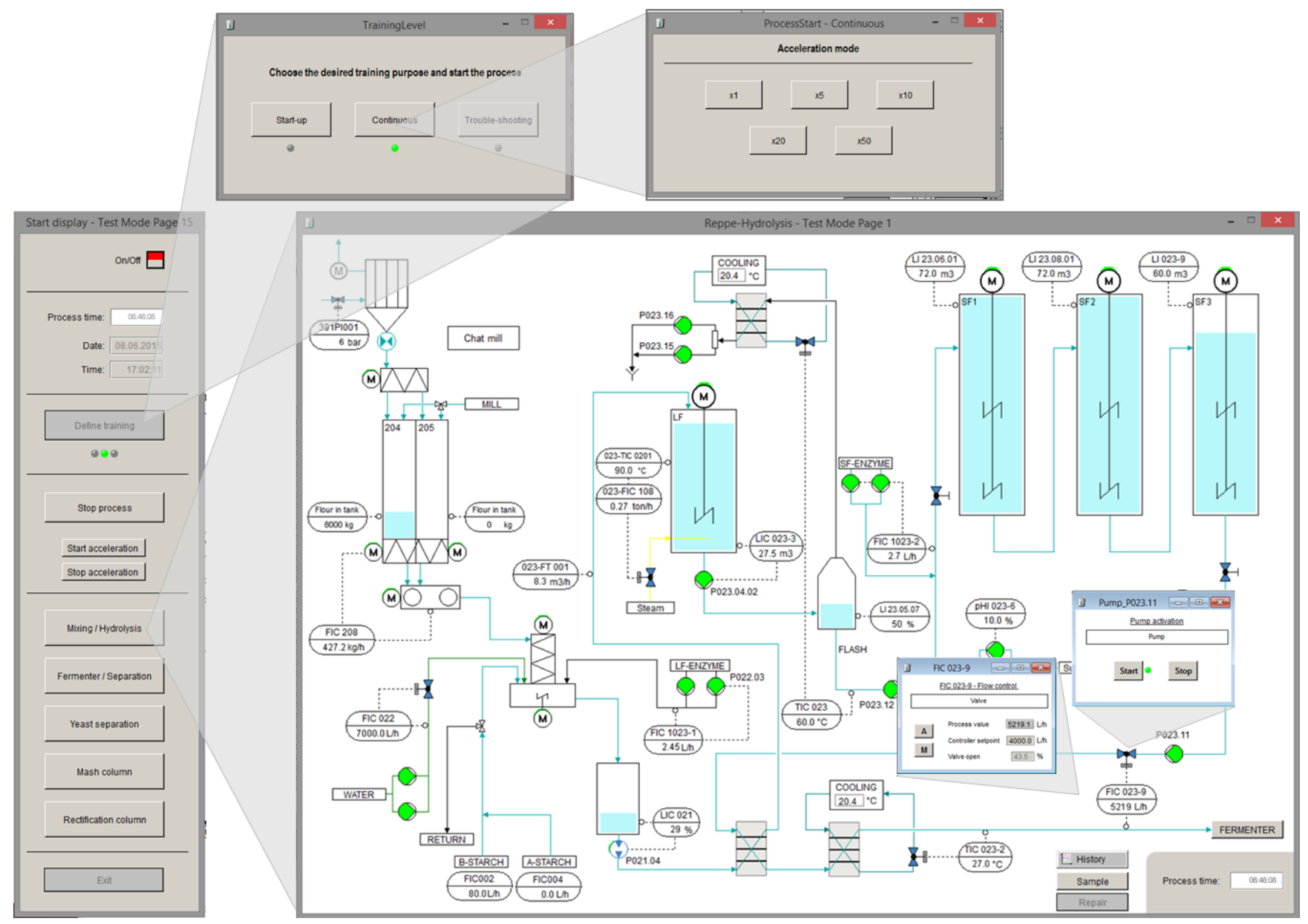

Figure 3: Biorefinery OTS developed using C-eStIM/WinErs ${ }^{7}$

Some innovative elements of this initial biorefinery model was the addition of a "communication management project" that allowed for communication between the individual unit models, thereby giving the operator the impression that he was working with a single integrated biorefinery. Additionally, it was possible to run the models at different speeds depending on the desired training target dictated by a plant's training requirements or the operators' capabilities. The developed OTS was used to train a number of students as well as industrial operators in the biomass power plant, with positive outcomes obtained in all cases. Although no objective evaluation of training effectiveness is presented, the authors report that there was a "significant improvement" in the capabilities of the trainees to run and evaluate the performance of real fermentation and distillation units.

In another pioneering contribution to the development of OTSs for bioprocesses, Gerlach et al. ${ }^{36}$ presented an OTS for virtual training of plant operators on the operational procedures and production skills required in recombinant protein production (RPP) processes. Gerlach et al. noted that in order for the model to accurately represent the complex interplay of factors in a RPP process, several metabolic interactions that affect biomass yield, productivity, and cellular viability must be captured in the OTS model. However, in order to maintain computational effectiveness, there is a need for compromise between model complexity 
and fidelity, by capturing the key metabolic processes in the OTS model that will closely match what happens in reality without making the model cumbersome and difficult to compute mathematically.

To develop the structured RPP model, the bioprocess trainer earlier developed by Hass et al. was coupled via dynamic link libraries (DLL) to the RPP-OTS model. The effectiveness of OTS training was evaluated by using the OTS for the education and training of bioengineering students. Some metrics used to assess the training effectiveness include fidelity of trainees' adherence to the standard operating procedure, awareness of key biological occurrences during the experiment, extent of focus during laboratory work, and the ability to explain and recollect key events during and after experimentation. Transfer of training was evaluated by comparing a group of trainees who were first trained using the RPP-OTS before being placed in the laboratory to run the experiments, with another set of trainees who were asked to run the experiments without prior exposure using the RPP-OTS. For all metrics assessed, the former group scored higher, demonstrating that there is potential benefit in using an OTS for the training of new process operators in bioprocess facilities.

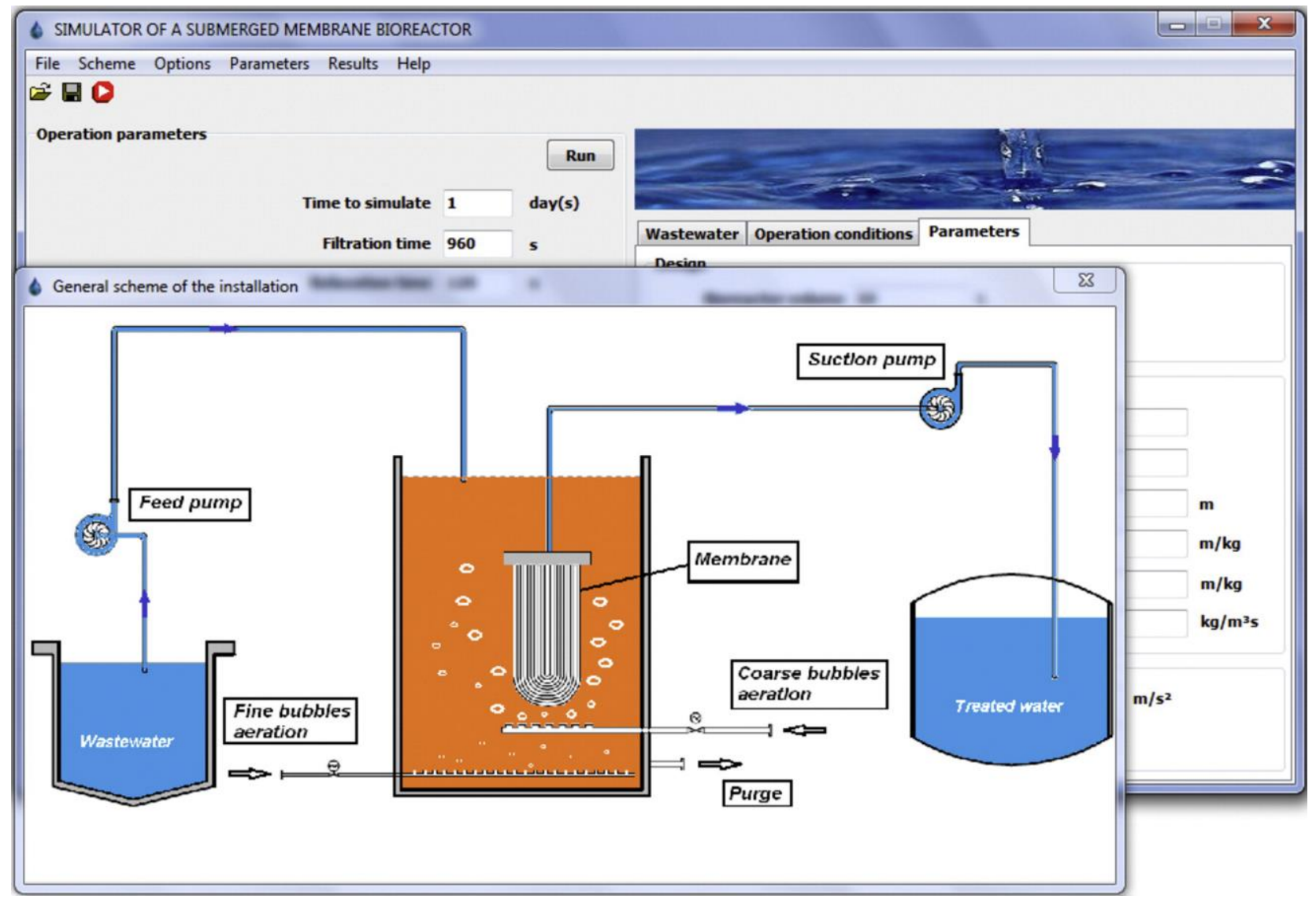

Figure 4: Biorefinery OTS developed using Delphi20096

In another contribution to the development and use of OTS in industrial biotechnology, Hass et al.40 presented a study on resource efficiency and energy conservation in bioethanol plants, using an OTS. The authors note that effective process control and automation strategies are necessary to ensure energy and resource efficiency. Training operators to effectively accomplish both tasks using an OTS therefore has a direct impact on a bioethanol plant's long-term profitability, as it will make it possible to reduce variable operating costs.

\section{OTS Design and Use in Large Scale Biorefineries}

The presence of large-scale biorefineries in North America means that there is a need for highly skilled process operators to run these plants efficiently. In recent years, a number of commercial-scale bioethanol operator training simulators of actual industrial plants have been developed specifically to train operators 
for these biorefineries. NovaTech's Ethanol and BioFuels Plant Simulator is one such example, developed in conjunction with a community college (http://www.novatechweb.com/).

Similarly, the interactive biorefinery operations simulator (I-BOS) was developed ${ }^{41}$ to teach biorefinery concepts to students enrolled at lowa State University's bio-renewable resources and technology programme. The simulator, located in lowa (America's corn belt where there is a large concentration of bioethanol plants), is modelled after real operating biorefineries producing ethanol and diesel in the region. Although these OTSs are reportedly being used for training in biorefineries, there is no scientific record of their development and deployment, nor any attempt was made by the commercial or academic developers to assess the effectiveness of these training simulators.

Gerlach and others ${ }^{7}$ describe the design of an OTS for an industrial scale bioethanol plant, with bioreactors ranging in size from 30 to $280 \mathrm{~m}^{3}$. This is the first recorded academic publication to address OTS development in an industrial large-scale biorefinery. Gerlach et al. employ a structured method for OTS development, including rigorous evaluation of the training needs of industrial operators, and an assessment of several OTS configurations to meet the identified training needs. The authors recommended that further work needs to be carried out to quantify the effectiveness of OTSs developed for large scale industrial biorefineries.

\section{Methods for Evaluating OTS Effectiveness}

The primary aim of developing an operator training simulator is to improve operator competence through training and education, by reducing the time required to attain competence and eliminating the risks associated with training in a "live" process plant. In the context of this review paper, it is important to distinguish between the terms "training" and "education".

According to Sutton ${ }^{42}$, "training refers to the process of assisting a trainee to develop the ability to carry out a routine and predefined task in a safe and efficient manner". An example is training an operator on how to start a pump, which will consist of a list of instructions, in the form of a standard operating procedure (SOP), which, when followed accurately, will lead to the pump being started in a safe and efficient manner. Education, on the other hand, teaches basic principles. If the operator who has been trained to start a pump is educated on the basic principles of pump operations, he would know what to do if the pump malfunctions or when he notices abnormal behaviour in pump operation. Effective training of process operators is usually accomplished using step by step guides written in standard operating and maintenance procedures. There are several examples in the academic literature where an OTS has been developed and used for the education and training of undergraduate students $22,36,33$, or for training industrial process plant operators ${ }^{43,44}$.

Nazir et al. ${ }^{45}$ describe an empirical method for assessing the effectiveness of operator training using an OTS - a method that is consistent, reliable, systematic and verifiable according to the researchers. A number of key performance indicators (KPls) are selected for assessing operator performance in an experimental scenario involving the $\mathrm{C} 3 / \mathrm{C} 4$ hydrocarbons separation section of a crude oil refinery, containing flammable and hazardous materials. The simulated accident scenario involves the release of high pressure liquid butane from a ruptured pipe flange hit by an excavator working in close proximity. Liquid hydrocarbon pool is subsequently ignited by an external ignition source. Selected KPIs for assessing operator competence include hydrocarbon pool diameter, response time, correct valve identification, and the number of times an operator asks for assistance before and after training. The results show that operators trained using an OTS were better at handling process upsets compared to those who were trained with traditional PowerPoint presentation.

Lathan and his fellow workers ${ }^{46}$ list the advantages and disadvantages of eight different methods of assessing the effectiveness of training simulators. Their findings are summarized in Table 4 . Of the methods described, the transfer of training method is commonly reported in the academic literature as a method for assessing OTS effectiveness ${ }^{36,45}$. Of the methods listed in Table 4, the self -control transfer of training appears to be a practical methodology. This is because using the same set of operators for evaluation will allow for consistency, and reduce the number of participants required for training evaluation. Using new or inexperienced operators for evaluation testing will provide valuable proof that operational improvements are the result of OTS training. 
Table 4: Pros and Cons of different methods for assessing OTS effectiveness

\begin{tabular}{|c|c|c|}
\hline Method of Evaluation & Description & Pros/Cons \\
\hline Operator opinion & $\begin{array}{l}\text { Operators, instructors, trainers, and students are } \\
\text { asked to give their opinions on perceived value of } \\
\text { simulator, its features, and possible impact on real } \\
\text { world performance. }\end{array}$ & $\begin{array}{l}\text { Useful when actual training or OTS } \\
\text { performance testing not feasible. Assumes } \\
\text { objectivity and may fail to recognise such } \\
\text { opinion could be based on previous knowledge } \\
\text { and/or experience. }\end{array}$ \\
\hline Assessment of fidelity & $\begin{array}{l}\text { Describes physical similarity between simulator and } \\
\text { real world environment, equipment, interface or facility. }\end{array}$ & $\begin{array}{l}\text { Assumes higher fidelity will lead to higher } \\
\text { transfer (common in commercial aircraft } \\
\text { industry). Regulatory requirements mean these } \\
\text { are used as assessment rather than training } \\
\text { tools. }\end{array}$ \\
\hline $\begin{array}{l}\text { Transfer of Training (ToT) } \\
\text { method }\end{array}$ & $\begin{array}{l}\text { Two groups of trainees: one group receives simulator } \\
\text { training prior to testing, while the other receive all their } \\
\text { training in the real world or some other method. Check } \\
\text { for similar prior experience and training between } \\
\text { groups. }\end{array}$ & $\begin{array}{l}\text { Generally, most appropriate to determine } \\
\text { whether training has improved subsequent } \\
\text { operational performance. }\end{array}$ \\
\hline Self-control ToT & $\begin{array}{l}\text { Uses experimental group to serve as own controls. } \\
\text { Assess operational performance, deliver simulator } \\
\text { training, and reassess operational performance and } \\
\text { compare with initial performance. }\end{array}$ & $\begin{array}{l}\text { Time interval between performance } \\
\text { assessments must be taken into account. } \\
\text { Assumes (rather than proves) performance } \\
\text { improvement is the result of simulator training. }\end{array}$ \\
\hline Pre-existing control ToT & $\begin{array}{l}\text { Determines ToT using simulator and assesses based } \\
\text { on known performance of individual operators. }\end{array}$ & $\begin{array}{l}\text { Simulator introduced after existing training } \\
\text { protocol is in place. }\end{array}$ \\
\hline Uncontrolled ToT & $\begin{array}{l}\text { Simply determines if naïve subjects can perform a } \\
\text { particular task in an operational setting following } \\
\text { simulator training. }\end{array}$ & $\begin{array}{l}\text { Crude way to determine training transfer } \\
\text { Useful for quick evaluation of features or } \\
\text { improvements to simulator. Does not provide } \\
\text { effective measure to accurately quantify } \\
\text { transfer. }\end{array}$ \\
\hline Inverse/Backward ToT & $\begin{array}{l}\text { Experts at the operational task perform the same tasks } \\
\text { using an OTS, without prior practice. A positive result } \\
\text { assumes that simulator is useful for training. }\end{array}$ & $\begin{array}{l}\text { Experienced operator is already proficient at } \\
\text { task and may have generalised skills. } \\
\text { Simulator may be effectively designed for } \\
\text { evocation of a particular set of behaviours from } \\
\text { a skilled operator. }\end{array}$ \\
\hline Simulator-to-simulator ToT & $\begin{array}{l}\text { Lower fidelity simulator used in part task training, } \\
\text { followed by whole task testing (or part testing) on a } \\
\text { higher fidelity simulator. }\end{array}$ & $\begin{array}{l}\text { Reduces use of more complex simulators } \\
\text { Implicitly assumes higher fidelity simulator will } \\
\text { lead to higher transfer of training. }\end{array}$ \\
\hline
\end{tabular}




\section{Future considerations}

An evolving trend in the design of training simulators is the integration of training simulators for both control room and field operators using virtual reality technologies. Traditional 2D simulators are typically used to train control room operators, with simple remote communication routines incorporated to allow for interaction between control room and field operators. A 3D emulation of important processing elements in the field can be used to offer virtual reality training for both control room and field operators. Examples of such 3D virtual reality simulators have been reported by several authors ${ }^{54-56}$.

Furthermore, the integration of operating procedure adaptation algorithms in an OTS for defining and finetuning operational strategies in addition to operator training is an emerging area of interest. Because of the complex nature of SOP synthesis, automation methods that reduce the chances of human error in the activity are widely reported ${ }^{47-50}$. Several reasons have been adduced for this automation. Manual synthesis of SOPs is time consuming and error prone. Generating an SOP for a biorefinery of moderate complexity can take weeks or months of sustained effort of multidisciplinary teams of engineers and operators to accomplish ${ }^{49}$. Often, extensive oversight and verification is required for manually generated SOPs, leading to inefficient use of resources and time.

SOP adaptation provides the capability to alter actions defined in production recipes based on dynamically changing process variables. Automatic SOP adaptation involves automatic recipe adjustments to match desired process conditions. This could be because of differences in raw material (feed) properties, enzyme strength, or unexpected changes in intermediate product qualities. It also involves allocation of plant equipment to match varying production requirements. For instance, a stand-by equipment can be brought online automatically to increase plant throughput, based on pre-defined process parameters.

Adaptive optimal control algorithms that incorporate available measured information about the state of the process, while simultaneously dealing with missing information in a robust way such that these unavailable data do not significantly degrade overall process control performance, may be used for SOP adaptation in an OTS. Several authors have investigated the use of adaptive control mechanisms to reduce the effects of disturbances on process stability ${ }^{51-53}$.

\section{Conclusion}

This review has presented an overview of the current status of OTS development for use in biotechnological processes in general, with a closer consideration of OTS development and use in biorefineries. As new and more advanced biorefineries become operational in several regions of the European Union, and other parts of the world, the challenge to meet the demand for appropriately skilled operators to effectively run these plants will become even greater. Operator training simulators provide an effective tool for meeting this challenge. Several authors have demonstrated that developing a functionally useful OTS for use in biotechnological applications requires a user-centred approach that demonstrates clearly defined operator training needs obtained through the cooperation of all stakeholders involved in OTS development.

To adequately handle the extra complexities present in bioprocesses, a simple and cost effective OTS development tool is required. Of the development tools and environments reviewed in this paper, those that provide a flexible modelling environment integrated with tested process control and automation software appear to be the most promising going forward. Finally, as biorefining technologies reach maturity with multiple feedstock processing capabilities, OTSs will become increasingly important for the development of operating strategies. An adaptive OTS will make it possible for operators to efficiently cope with changing plant and process conditions, without loss of product quality and throughput.

\section{Acknowledgement}

This research work is being sponsored through the generous financial assistance of the Petroleum Technology Development Fund, PTDF, Nigeria. 


\section{References}

(1) Hass, V. C. Operator Training Simulators for Bioreactors, in Bioreactors: Design, Operation and Novel Applications (ed C.-F. Mandenius), Wiley-VCH Verlag GmbH \& Co. KGaA, Weinheim, Germany.ch16. (2016).

(2) Reinig G, Winter P, Linge V, Nägler K. Training Simulators: Engineering and Use. Chem Eng Technol; 21:711-716. (1998).

(3) Patle DS, Ahmad Z, Rangaiah GP. Operator training simulators in the chemical industry: review, issues, and future directions. Rev. in Chem. Eng. 30:199-216. (2014).

(4) Ahmad Al, Low Em, Abd Shukor Sr. Safety Improvement and Operational Enhancement via Dynamic Process Simulator: A Review. Chem. Prod. and Proc. Modelling 5 (1) Available Online: https://doi.org/10.2202/1934-2659.1502. Accessed Sep. 2016. (2010).

(5) Blesgen A, Hass VC. Efficient Biogas Production through Process Simulation. Energy Fuels; 24:4721-4727. (2010).

(6) González Hernández Y, Jáuregui Haza UJ, Albasi C, Alliet M. Development of a Submerged Membrane Bioreactor simulator: a useful tool for teaching its functioning. Education for Chemical Engineers; 9: e32-e41. (2014). Figure reprinted with permission from Elsevier.

(7) Gerlach I, Hass VC, Carl-Fredrik Mandenius. Conceptual Design of an Operator Training Simulator for a Bio-Ethanol Plant. Processes; 3:664-683. (2015).

(8) Blanchard BS. System Engineering Management. 3rd ed. New York: John Wiley \& Sons; (2004).

(9) Mandenius C, Björkman M. Mechatronics design principles for biotechnology product development. Trends Biotechnol; 28:230-236. (2010).

(10) Chen H, Zhang Y-P. New biorefineries and sustainable agriculture: Increased food, biofuels, and ecosystem security. Renew. Sustain. Energy Rev. 47:117-132. (2015).

(11) Nasios K. Improving Chemical Plant Safety Training Using Virtual Reality PhD Thesis, University of Nottingham. Available Online: http://eprints.nottingham.ac.uk/10039/. Accessed Oct. 2016. (1999).

(12) Health and Safety Executive. A guide to the Control of Major Accident Hazards Regulations (COMAH) 2015. Available at: http://www.hse.gov.uk/pUbns/books//111.htm, Accessed Aug. 2016. (2015).

(13) International Energy Agency. IEA Bioenergy Update - IEA Bioenergy Task 42. Biomass Bioenergy 86: I-V. (2016).

(14) Bioebergy2020+, Commercialising Liquid Biofuels from Biomass. Available: http://demoplants.bioenergy2020.eu/. Accessed 03 January 2017. (2016).

(15) Luque, R., Campelo, J. \& Clark, J.H., Handbook of biofuels production: processes and technologies 2nd ed. Oxford; Woodhead Pub. (2011).

(16) Elliott CD. Chemicals from Biomass. In Encyclopaedia of Energy. Volumes 1 - 6. ed. Cleveland CJ, Online version available: http://app.knovel.com/hotlink/toc/id:kpEEV00001/encyclopedia-energyvolumes/encyclopedia-energy-volumes [Accessed 17 March 2016]. New York: Elsevier; p. 163-174. (2004).

(17) Finlay MR. Old Efforts at New Uses: A Brief History of Chemurgy and the American Search for Biobased Materials. J Ind Ecol;7:33-46. (2003).

(18) European Biofuels Technology Platform. Global biofuels - an overview. Available at: http://www.biofuelstp.eu/global_overview.html, Accessed Nov. 2016. (2016). 
(19) International Energy Agency. Medium-Term Renewable Energy Market Report 2015, OECD/IEA, Paris. Available at: https://www.iea.org/topics/renewables/subtopics/bioenergy/, Accessed Oct. 2016. (2015).

(20) Jungmeier G, van Ree R, Jørgensen $\mathrm{H}$, de Jong $\mathrm{E}$, Stichnothe $\mathrm{H}$, Wellisch M. The Biorefinery Fact Sheet. IEA Bioenergy, Available online http://www.iea-bioenergy.task42biorefineries.com/en/ieabiorefinery.htm, Accessed Jun. 2016 (2014).

(21) Bisaria VS, Kondō A, eds. Bioprocessing of Renewable Resources to Commodity Bioproducts. Wiley, New Jersey; 584pp, (2014).

(22) Hass VC, Kuhnen F, Schoop K. An environment for the development of operator training systems (OTS) from chemical engineering models. Computer Aided Chemical Engineering; 20:289-293. (2005).

(23) Schoop K-. WinErs: Process control and automation system on PC under Windows; Available at: http://www.schoop.de/index.php/en/software/winers. Accessed Online, Accessed Nov. 2016, (2008).

(24) Hubka V, Ernst Eder W. A scientific approach to engineering design. Design Stud. 8:123-137. (1987).

(25) Ulrich KT, Eppinger SD. Product Design and Development. 3rd ed. McGraw-Hill, Boston, Mass; (2003).

(26) Chan L, Wu M. Quality function deployment: A literature review. Eur J Oper Res 143:463-497. (2002).

(27) Govers CPM. What and how about quality function deployment (QFD). Int J Prod Econ 12:575-585. (1996).

(28) Juran JM. Juran on quality by design: the new steps for planning quality into goods and services. New York: Free Press; (1992).

(29) Anurag SR, Winkle H. Quality by design for biopharmaceuticals. Nat Biotechnol; 27:26. (2009).

(30) Sheng-Hsien T, Shin-Yann H. Failure mode and effects analysis; An integrated approach for product design and process control. Int. J. Qual. \& Rel. Manag. 13:8-26. (1996).

(31) Ginn D, Jones D, Rahnejat H, Zairi M. The " QFD/ FMEA interface". Eur. J. Innov. Mgmt. 1:7-20. (1998).

(32) Tan CM. Customer - focused build - in reliability: a case study. Int J Qual \& Rel. Mgmt. 20:378-397. (2003).

(33) Pavé A. Modelling living systems: from cell to ecosystem. Wiley, London; 620pp. (2012).

(34) Gerlach I, Hass VC, Brüning S, Mandenius C. Virtual bioreactor cultivation for operator training and simulation: application to ethanol and protein production. J Chem Technol Biotechnol 88:2159-2168. (2013).

(35) Hass VC, Kuntzsch S, Gerlach I, Kuhn K, Winterhalter M. Towards the Development of a Training Simulator for Biorefineries. Chem Eng Trans 29:247-252. (2012).

(36) Gerlach I, Brüning S, Gustavsson R, Mandenius C, Hass VC. Operator training in recombinant protein production using a structured simulator model. J Biotechnol 177:53-59 (2014).

(37) Ahmad Z, Patle DS, Rangaiah GP. Operator training simulator for biodiesel synthesis from waste cooking oil. Process Safety Environ Prot 99:55-68. (2016). Figure reprinted with permission from Elsevier.

(38) Balaton M, Nagy L, Szeifert F. Operator training simulator process model implementation of a batch processing unit in a packaged simulation software. Comput Chem Eng 48:335-344. (2013). 
(39) Gerlach I, Mandenius C, Hass VC. Operator training simulation for integrating cultivation and homogenisation in protein production. Biotechnology Reports 6:91-99. (2015).

(40) Hass VC, Kuntzsch S, Schoop K. Resource Efficiency Studies using a New Operator Training Simulator for a Bioethanol Plant. Chem. Eng. Trans. 39:541-546. (2014).

(41) Grewell D. Learn to run a biorefinery in a virtual control room, developed by lowa State researchers. Available at: http://www.news.iastate.edu/news/2011/apr/virtualcontrolroom. Accessed 10 January, 2016. (2011).

(42) Sutton I. Chapter 7 - Training and Competence. In Process Risk and Reliability Management (Second Edition), Sutton I, editor, Gulf Professional Publishing, Oxford; p. 370-389. (2015)

(43) Dozortsev V. Development of computer- based training simulator for industrial operators: Main participants, their roles and communications. Autom. Remote Control 71:1476-1480. (2010).

(44) Borsci S, Lawson G, Broome S. Empirical evidence, evaluation criteria and challenges for the effectiveness of virtual and mixed reality tools for training operators of car service maintenance. Comput Ind 2:17-26. (2015).

(45) Nazir S, Colombo S, Manca D. Testing and analyzing different training methods for industrial operators: an experimental approach. Computer Aided Chemical Engineering 32:667-672. (2013).

(46) Lathan CE, Tracey MR, Sebrechts MM, Clawson DM, Higgins GA. Chapter 19 Using virtual environments as training simulators: measuring transfer. In: Handbook of virtual environments: design, implementation, and applications, Hale KS, Stanney KM, editors. Lawrence Erlbaum Associates, London, p. 403-414. (2002).

(47) Rivas, J.R., Rudd, D.F. \& Kelly, L.R. .Computer- aided safety interlock systems, AIChE Journal, vol. 20, no. 2, pp. 311-319. (1974).

(48) Pradubsripetch, D., Lee, S., Adriani, A. \& Naka, Y. Real time generation of operating procedures to support flexible start-up operation, Computers and Chemical Engineering, vol. 20, pp. S1203-S1208. (1996).

(49) Viswanathan, S., Johnsson, C., Srinivasan, R., Venkatasubramanian, V. \& Ärzen, K.E. Automating operating procedure synthesis for batch processes: Part I. Knowledge representation and planning framework", Computers and Chemical Engineering, vol. 22, no. 11, pp. 1673-1685. (1998).

(50) Srinivasan, R., Sundarraman, A., Viswanathan, P.K., Vedam, H. \& Ananthanarayanan, N. Method and apparatus for monitoring process transitions, US Patents, vol. US7233882 B2. (2007).

(51) Ramaswamy, S., Cutright, T.J. \& Qammar, H.K. Control of a continuous bioreactor using model predictive control. Process Biochemistry 40 (8):2763-2770. (2005)

(52) Jang, M., Chern, Y. \& Chou, Y. Robust adaptive controller for continuous bioreactors. Biochemical Engineering Journal 81:136-145. (2013)

(53) Bouraoui, I., Farza, M., Menard, T., Abdennour, R.B. \& M'Saad. On-line estimation of the reaction rates from sampled measurements in bioreactors", IFAC-Papers OnLine, 49 (7): 1205-1210. (2016)

(54) Manca D, Brambilla S, Colombo S. Bridging between Virtual Reality and accident simulation for training of process-industry operators. Adv Eng Software 55:1-9. (2013).

(55) EON Reality. Immersive 3D Operator Training Simulator Technology. Available at: http://www.eonreality.com/press-releases/exxonmobil-awards-license-to-eon-reality-forimmersive-3d-operator-training-simulator-technology/. Accessed Nov., 2016. (2015)

(56) Honeywell Process Solutions. Training suite to improve operator competency through 3D simulation. Control Engineering Magazine, Available online Accessed Oct 2016. http://www.controleng.com/single-article/training-suite-to-improve-operator-competency-through-3dsimulation/b61e8da5f6002bbcf2038c4269b6d81d.html, (2015). 